\title{
Comparison distribution of Vibrio species in stocking to harvesting process of shrimp at commercialize shrimp farm
}

\author{
Elexson Nillian*, Nur Diyana Zakaria, Dalene Lesen, Nur Hafizah Mohd Yusoff, \\ Nurain Syahirah Binti Ismail, Teng Sing Tung, Lesley Bilung \\ Faculty of Resource Science and Technology, University Malaysia Sarawak, \\ 94300, Kota Samarahan, Sarawak, Malaysia \\ *Corresponding author e-mail: nelexson@unimas.my
}

Received: June 3, 2021. Revised: December 19, 2021. Accepted: January 14, 2022.

Published: January 21, 2022.

\begin{abstract}
Vibrio species is one of the pathogenic bacteria infecting shrimps in aquaculture farm has caused severe loss to the aquaculture farm. The aim of this research is to isolate and compare the presence of Vibrio spp. in commercialize shrimp farm during the stocking process and the final harvest phase of shrimp productions. Quantification and isolation were conducted and measured using Log CFU (colony forming units) counts and morphological investigation gram staining and conventional biochemical test identification. A total of sixty-four $(n=64)$ sediment and water samples were collected from the inlet and outlet of the two selected shrimp ponds (Pond $A$ and Pond $B$ ) in Kampung Telaga Air, Kuching, Sarawak. As a result, the bacteria count from water samples during stocking period at both shrimps ponnds were 6.6 Log CFU/ml and 5.6 Log CFU/ml while during harvesting period were $5.3 \mathrm{Log}$ CFU/ml and $5.8 \mathrm{Log}$ CFU/ml. Meanwhile, bacteria count sediments samples during stocking period at both shrimp ponds were $5.5 \mathrm{Log} \mathrm{CFU} / \mathrm{g}$ and $5.7 \mathrm{Log}$ CFU/g whereas harvesting period at showed both shrimps pond were $5.2 \mathrm{Log} \mathrm{CFU} / \mathrm{g}$ and $4.8 \mathrm{Log} \mathrm{CFU} / \mathrm{g}$. The finding showed the Vibrio sp. identified in sediment samples were $V$. parahemolyticus with $27 \%$, followed by $V$. alginolyticus $(22 \%)$, $V$. cholerae (16\%). V. fluvialis (14\%) and $7 \%$ of $V$. fulmisi and $V$. vulnificus and $V$. mimicus. Meanwhile, the Vibrio sp. identified in water samples were $V$. fluvialis with $29 \%$, followed by $V$. alginolyticus $(22 \%)$, V. parahemolyticus $(19 \%)$ and $10 \%$ were $V$. fulmisi, $V$. mimicus and $V$. vulnificus. The study has been carried out further by investigated the Antibiotic Susceptibility Test (AST) using erythromycin $(15 \mathrm{ug} / \mathrm{ml})$, ampicillin $(10 \mathrm{ug} / \mathrm{ml})$, and streptomycin $(25 \mathrm{ug} / \mathrm{ml})$. The positive cultures from sediment samples showed Ampicillin resistant profile was $>0.2$ MAR index while fifty percent $(50 \%)$ of the isolates from water samples were resistant to ampicillin. Therefore, this study has profound implications for further monitoring process from the stocking process towards the harvesting process in order to prevent any Vibrio sp. infection which caused shrimp's disease or food safety issue related to public consumption or of shrimps in future.
\end{abstract}

Keywords-Antibiotic-resistant profile, antibiotic susceptibility test, shrimp aquaculture farm, stocking vs. harvesting, Vibrio sp.

\section{INTRODUCTION}

quaculture is defined by Food and Agriculture Organization (FAO) (2013), as the farming of aquatic organisms such as fish, mollusks, crustaceans and aquatic plants [1]. Farming of the aquatics organisms implies some procedure to enhance the production. The process involves regular stocking, feeding, and protection from predators or harmful diseases. Aquatics organisms which are harvested for export purposes must go through several stages of export compliances with the local authorities prior to be marketed as it is considered the most traded food supply for the world. According to FAO (2010), aquaculture has the potential to meet the increasing global demand for nutritious seafood and to contribute in the aspect of national economies besides supporting the sustainable livelihoods of human communities [2]. According to the South East Asian Fisheries Development Center (SEAFDEC), the contribution from Malaysian aquaculture industries was 506,454 tonnes valued at MYR 3.3 billion in year 2016. Approximately 100000 tonnes comes from freshwater products while marine products consist approximately 400000 tonnes of the production.

Increasing demand from international market and decreasing percentages of shrimp catch lead to the blooming of commercial shrimp aquaculture in many countries including Malaysia [3]. Penaied species, also known as shrimp, such as P. vannamei (white leg shrimp) and P. monodon (tiger shrimp) which are the widely used products from shrimp aquaculture were cultivated in Asian [4]. Shrimp cultivation which usually located at estuary and coastal area also provide job opportunities and better livelihood for local people. 
However, the shrimp farming industry is constantly under threat due to the outbreak of infectious diseases and environmental problems. Bacteria are among the groups of microorganisms giving the negative impacts on global shrimp industries. Vibrio genus, including $V$. cholarae, $V$. paraheamolyticus, V. mimicus, $V$. harveyi, $V$. alginolyticus, and $V$. vulnificus have been described as pathogenic species in shrimp production environment [5]. These pathogens cause serious infections and decreased the amount of production.

Vibrio sp. naturally can be found in aquatic environment and it is usually a naturally occurring bacteria at the shrimp agriculture industries [6]. The bacteria are also commonly found in sediments and seawater [7]. Ecological parameters such as temperature, salinity, $\mathrm{pH}$ and nutrient had affected the appearance and the abundance of Vibrio sp. in water [8]. The shrimp aquaculture in coastal areas had been reported as a place with abundance of the Vibrio sp. to live and grow due to favourable environment. The growth escalation of the pathogenic Vibrio sp. may cause mortality to the shrimp. This is because when the number of this bacteria increases in the system of the shrimp, the shrimp will become weakened and eventually became the carrier of the viruses [9].

Hence, determination of Vibrio sp. in the aquaculture shrimp farm is very useful for management of the farm and to prevent any diseases that can cause harm to the shrimp that were being cultured. Thus, in this study, Vibrio sp. in shrimp pond were isolated and the presence of Vibrio sp. in shrimp farm during the first phase of production (stocking process) and the final phase of production (harvesting process) were being compared in order to investigate the bacteria distribution. In addition, the susceptibility of antibiotics has been determined in order to prepare the corrective action reaction the future treatment related to Vibrio sp. diseases occurrence.

\section{MATERIALS AND METHODS}

\section{A. Sample collection}

The study was performed on two $(n=2)$ selected ponds (Pond A and Pond B) of the commercialize shrimp farm in Kampung Telaga Air, Kuching, Sarawak. The ponds were selected based on the stocking period base on permission and availability determined by the farmer of the shrimp's farm. Hence, only two ponds were chosen for the sample collection. The sampling process were conducted for four times which is two times during first phase stocking process and two times during final harvesting process of the cultures. A total of sixtyfour $(n=64)$ sediment and water samples were collected from two different ponds. A total of hundred $(n=100) \mathrm{g}$ of sediment samples were collected at $20 \mathrm{~cm}$ depth from surface while for the water samples, $500 \mathrm{ml}$ was taken for each site with $10 \mathrm{~cm}$ depth from the surface.

\section{B. Bacterial quantification}

The samples were examined by following the procedure from Bacteriological Analytical Manual for the identification process of the Vibrio sp. [10]. Tenfold dilutions were conducted by using APW (alkaline peptone water) for dilution of the samples and then spread on TCBS agar [11]. The number of colonies on the plates were counted after 24-hours incubation.

\section{Biochemical tests}

The colonies on TCBS agar were selected for identification process. Gram staining were conducted to classify the group of the colonies whether gram positive or gram negative. Then, the species of the bacteria were confirmed by conducting biochemical test including salt tolerant, VP (VogesProskauer), oxidase and carbohydrate fermentation test using D-cellobiose and sucrose. Procedure for biochemical test were conducted and interpreted according to Bergey's Manual of Systemic Bacteriology [12].

\section{i. Oxidase Test}

Oxidase test was performed by using oxidase strip. A toothpick was sterilised and used to pick the isolated bacteria. The colony was streaked on oxidase strip gently. If the isolated bacteria produce cytochrome oxidase, the strip will produce blue or purple colour within 15 seconds. The isolates that lacking of cytochrome $\mathrm{c}$ or do not produces cytochrome oxidase will show negative result with no colour change.

\section{ii. Voges-Proskauer (VP) tests}

Pure single colonies of the isolates were inoculated into the test tube containing MRVP broth and incubated at $37^{\circ} \mathrm{C}$ for 24 hours. After incubation process, $1 \mathrm{~mL}$ of the broth was aliquot into another sterile test tube. Then, $0.6 \mathrm{ml}$ of reagent $\mathrm{A}$ and 0.2 $\mathrm{ml}$ of reagent $\mathrm{B}$ were added to the test tube. Ratio of reagent $\mathrm{A}$ and $\mathrm{B}$ should always be $3: 1$. The mixtures were shaken gently to allow the exposition of medium to atmospheric oxygen. The medium was left undisturbed for 15 to 30 minutes before the results were observed. The existence of red colour represented the positive results, while brown colour or colour remains unchanged was considered as negative.

\section{iii. Salt Tolerance Test}

The tubes with the mixtures of peptone water and different percentage of sodium chloride $(\mathrm{NaCl})$ were prepared. The percentage of $\mathrm{NaCl}$ used in this test were $0,3,6,8$ and $10 \%$ $\mathrm{NaCl}$. The isolated bacteria were then inoculated using sterile loop and were incubated for 24 hours at $37^{\circ} \mathrm{C}$. The results were taken after the incubation. The positive results can be determined by observing the turbidity of the medium. The turbidity of the medium indicated the growth of bacteria while those with no growth remained clear.

\section{iv.Acid fermentation}

The test was conducted by preparing for the medium of the test as being mentioned in the list of materials. The acid fermentation test was conducted by using two types of carbohydrates which are D-cellobiose and sucrose. The bacterial isolates were inoculated using sterile loop and left 
incubated for 24 hours at $37^{\circ} \mathrm{C}$. After the incubation process, the medium was observed. The positive results of the test can be determined by observing on the colour change of the medium. If the purple colour of the medium turns to the yellow, it shows the positive results while the unchanged of colour indicated the negative results.

\section{Antibiotic susceptibility test (AST)}

The antibiotic susceptibility test was carried out using the disk diffusion method on the MHA (Mueller-Hinton agar) plates, which follow the established guidelines by Bauer et al. [13]. The OD (optical density) of the samples were adjusted to 0.6 MacFarland standard using spectrophotometer. The common has been use in aquacultures antibiotics were performend using erythromycin $(15 \mathrm{ug} / \mathrm{ml})$, ampicillin (10 $\mathrm{ug} / \mathrm{ml})$, and streptomycin $(25 \mathrm{ug} / \mathrm{ml})$ to investigate the antibiotic resistant profile of the Vibrio sp. The diameter of the zone of inhibition were measured using a ruler and data were recorded following the guidelines from Clinical and Laboratory Standards Institute (CLSI), Performance Standards for Antimicrobial Susceptibility Testing M100, 28th edition. MAR index of each antibiotic were calculated.

\section{E. Statistical Analysis}

All measurements were carried out in three duplicate and reported as the mean \pm of independent trials. Terms with higher $\mathrm{p}$-value $(\mathrm{p}>0.05)$ were statistically considered nonsignificant on the response variable. All data was analyzing using Microsoft Office Excel 2007.

\section{RESULTS}

The bacteria count from water samples during stocking period at Pond A were 6.6 Log CFU/ml while at Pond B were 5.6 Log CFU/ml. However, the bacteria count from water samples during harvesting period at Pond A were 5.3 Log $\mathrm{CFU} / \mathrm{ml}$ while at Pond B were 5.8 Log CFU/ml. For sediments samples, the bacteria count during stocking period at Pond A were $5.5 \mathrm{Log} \mathrm{CFU} / \mathrm{g}$ while at Pond $\mathrm{B}$ were $5.7 \mathrm{Log} \mathrm{CFU} / \mathrm{g}$ whereas during harvesting period at Pond A were $5.2 \mathrm{Log}$ $\mathrm{CFU} / \mathrm{g}$ while at Pond B were $4.8 \mathrm{Log} \mathrm{CFU} / \mathrm{g}$. All the results were shown in Figure 1 and Figure 2.

The physio-chemical parameters and abundance of the Vibrio sp. in shrimps pond A and B from water and sediments samples during stocking and harvesting were shown in Table 1.
Table 1. The physio-chemical parameters and abundance of Vibrio sp. in pond A and pond B of aquaculture shrimp farm during stocking to harvesting process

\begin{tabular}{|c|c|c|c|c|c|c|}
\hline \multicolumn{7}{|c|}{ Stocking process } \\
\hline & \multicolumn{4}{|c|}{ Parameters } & \multicolumn{2}{|c|}{$\begin{array}{l}\text { No of bacteria } \\
\text { (Log CFU/ml) }\end{array}$} \\
\hline & $\mathrm{pH}$ & $\begin{array}{c}\text { Temperature } \\
\left({ }^{\circ} \mathrm{C}\right)\end{array}$ & $\begin{array}{l}\text { Dissolved } \\
\text { Oxygen }\end{array}$ & $\begin{array}{l}\text { Salinity } \\
\text { (PPT) }\end{array}$ & Water & Sediment \\
\hline Pond A & $3 \pm 7.42$ & $3 \pm 29.2$ & $3 \pm 7.5$ & $3 \pm 9$ & 6.6 & 5.5 \\
\hline Pond B & $3 \pm 7.46$ & $3 \pm 30.7$ & $3 \pm 6.6$ & $3 \pm 10$ & 5.6 & 5.7 \\
\hline \multicolumn{7}{|c|}{ Harvesting process } \\
\hline Pond A & $3 \pm 7.93$ & $3 \pm 29.2$ & $3 \pm 6.4$ & $3 \pm 12$ & 5.3 & 5.2 \\
\hline Pond B & $3 \pm 7.47$ & $3 \pm 29.3$ & $3 \pm 5.5$ & $3 \pm 12$ & 5.8 & 4.8 \\
\hline
\end{tabular}

Log CFU/ml of Vibrio sp. in Pond A and Pond B from Water Samples

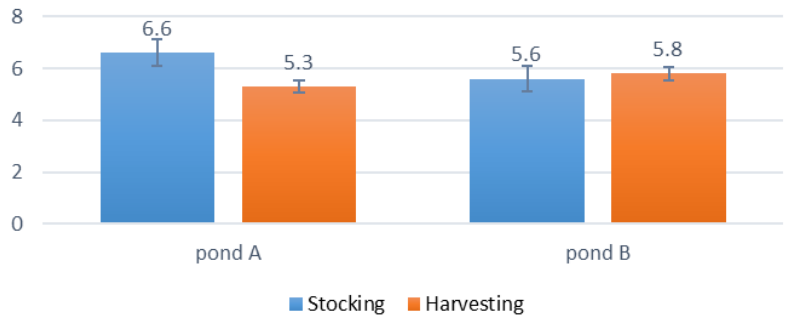

Figure 1. Comparison between Log CFU/ml of Vibrio sp. in pond $\mathrm{A}$ and pond $\mathrm{B}$ in water samples during stocking and harvesting process

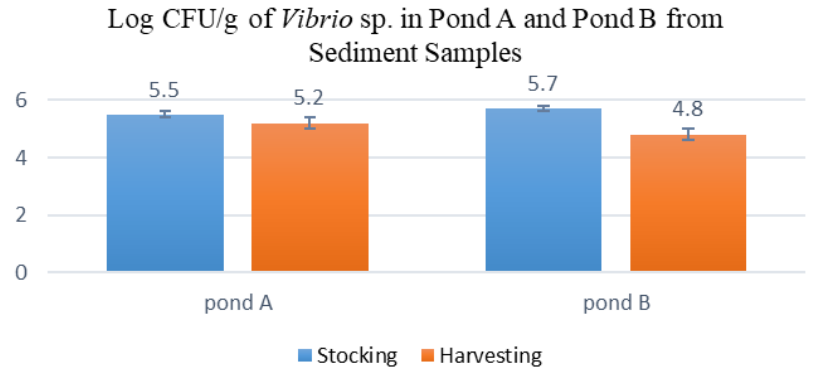

Figure 2. Comparison between total count of Vibrio sp. in pond $\mathrm{A}$ and pond $\mathrm{B}$ in sediment samples during stocking and harvesting process

During collection of water samples (Table 1), four parameters such as temperature, salinity, $\mathrm{pH}$ and dissolved oxygen had been recorded. All parameters were recorded at triplicates for every sampling to obtained the average $( \pm)$ reading as recorded in Table 1 and Figure 5 and 6.

Gram staining procedures were conducted to classify the group of the isolates whether gram negative or gram positive bacteria. Vibrio sp. were classified as gram negative bacteria which produce pink colour while gram positive bacteria show purple or violet colour. As tabulated in Figure 3 and Figure 4, the identification of the Vibrio colonies has been validated by conventional biochemical methods includes oxidase, salt 
tolerant, Voges-Proskauer and carbohydrates fermentation using D-cellobiose and sucrose to differentiate the species of the bacteria and identified the presumptive Vibrio colonies.

Figure 3 showed the highest Vibrio sp. identified in sediment samples was $V$. parahemolyticus with $27 \%$, followed by $V$. alginolyticus (22\%), V. cholerae (16\%). V. fluvialis (14\%) and least identified with $7 \%$ were $V$. fulmisi and $V$. vulnificus and $V$. mimicus during the stocking process and harvesting process.



Figure 3. Percentages of Vibrio sp. isolates during stocking and harvesting process from sediment samples

As referred to Figure 4, the highest Vibrios identified in water samples were was V. fluvialis with $29 \%$, followed by V. alginolyticus (22\%), V. parahemolyticus (19\%), and least identified with $10 \%$ were $\mathrm{V}$. fulmisi, V. mimicusand $\mathrm{V}$. vulnificus. However, there are no identification of V. cholera present in water samples during the stocking and harvest process. This is in agreement with [14], whereas the predominant species might be emerging compare to others species with limited nutrients from the environments.

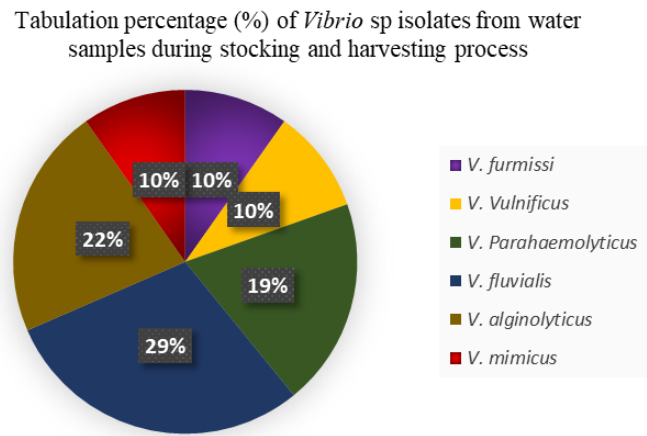

Figure 4. Percentages of Vibrio sp. isolates during stocking and harvesting process from water samples

Based on the AST test that have been performed, Vibrio sp. which is $83.33 \%$ from sediments samples are susceptible to the antibiotics while the percentage of Vibrio sp. that shows intermediate and resistant reaction are $11.46 \%$ and $5.20 \%$. while the others Vibrio sp. are resistant to one antibiotic with the MAR index 0.2. The antibiotics tetracycline and chloramphenicol shows $100 \%$ susceptibility to the Vibrio sp. isolates. For the isolates from water samples, the antimicrobial susceptibility test showed that V.mimicus and V. vulnificus are susceptibility to all the antibiotics. Meanwhile, the result of MAR Index for the isolated Vibrio sp. are $V$. damsela with 0.33 , V. furmissi with 0.33 and $V$. fluvialis with 0.17 . The MAR index more than 0.2 showed that the bacterial may origin from contaminated water sources and high exposure of antibiotics.

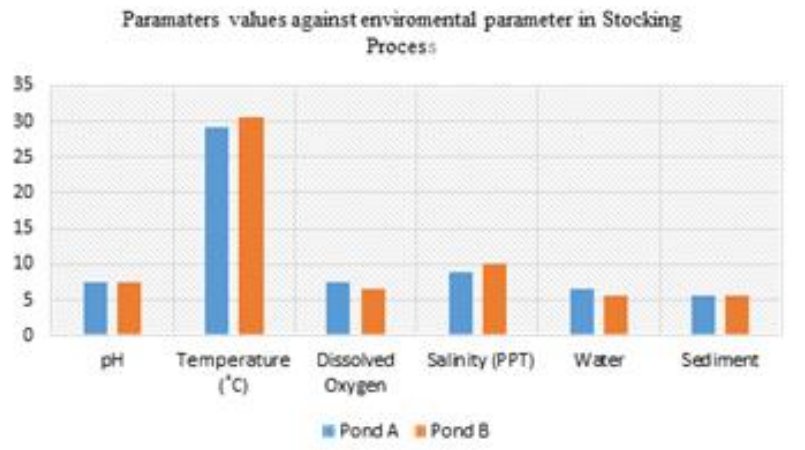

Figure 5. Parameters values against environment (Physiochemical) parameters during stocking process

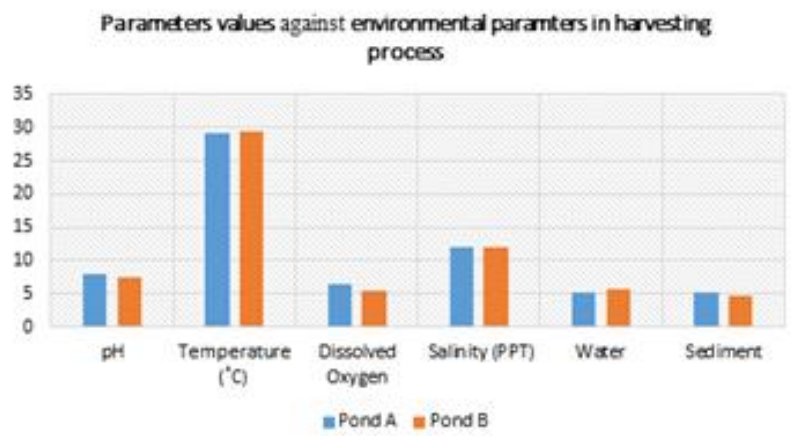

Figure 6. Parameters values against environment (Physiochemical) parameters during harvesting process

\section{DISCUSSION}

The high quantification numbers of bacterial presence in both sample collected as shown in Figure 1 and 2 indicates the potential biological hazard contamination which are related to the environmental management system in term of control and monitoring the hygiene and safety toward biological hazard. Thus, this can be improvised by ensuring the sanitization and disinfection process shall be in place including the facilities, equipment used, personal hygiene of the workers and water usage.

The high number of Vibrio sp. may cause infections of shrimp's diseases referred as vibriosis which can be detected with several symptoms such as black shell disease, tail rot, septic hepatopancreatic necrosis, brown gill disease, swollen hind gut syndrome, and luminous bacterial disease. Those infections have several number of clinical signs such as lethargy, loss of appetite, luminescence, yellowing of the gill tissue, and red discoloration of the body [15]. 
Microbiological hazard assessment of aquaculture systems as referred to Figure 3 and 4 will able to determine the growth potential shrimp's disease in aquaculture shrimp industry. The prevention from the risk of infection not only can be prevent toward shrimp's diseases but to assure the safety of consumption of raw seafood. Contamination could cause significant economic loss besides it may lead to consumption of unsafe shrimp to the consumers. Pathogenic bacteria can adhere to seafood from contaminated aquaculture environment such as water sources or the pond bottom itself [16]. According to FAO (2019), the high levels of Vibrio sp. is associated with the poor environmental management system in term of hygiene and safety may cause the shrimp to become weaken and susceptible to viral infection [17].

In order to prevent the disease from spreading from one pond to another, breeders shall cultivate and provide specific pathogen-free (SPF) shrimp stocks to the farmers. SPF shrimp stocks has improved in the shrimp production in many countries. However, strict management procedures such as using physical barriers, water treatment control, carrier exclusion, and feed management system are essential [18]. In addition, routine determination of Vibrio sp. in farms is important for the farmers prior to the managements decisions. As according to Verschuere, et al, preventive measure usually applied in order to disinfect and provide antimicrobial solutions [19].

According to Vincent et al., as referring to Table 1, the ecological parameters such as temperature, salinity, $\mathrm{pH}$ and nutrient had affects the abundance of Vibrio sp. in water [8]. Shrimp farmers shall conduct basic monitoring for the physico-chemical and microbiological characteristics of water by sustain the daily basis of record keeping for immediate and easy reference. In addition to the next cropping and essential for troubleshooting problems. Shrimp farmer should monitor the water depth, temperature, salinity and $\mathrm{pH}$ twice daily such as morning and in the evening in order to maintain the optimum conditions for growth and avoid any drastic changes of the parameters.

In shrimp farming, the salinity variation of water is considered a determinant factor in shrimp production. As referred to Figure 5 and 6 , the optimal level varies between species. The tiger shrimp ( $P$. monodon) grows faster at 15-30 ppt while the white leg shrimp ( $P$. indicus and $P$. merguiensis) tolerate higher salinity ranging from 25-40 ppt. Ideal temperature is 28 to $32^{\circ} \mathrm{C}$. The obtained temperature and $\mathrm{pH}$ in Table 1 showed the water in the pond provides an optimal condition for the Vibrio sp. to proliferate abundantly inside the farms. Vibrio sp. is able to tolerate a wide range of temperature $\left(20^{\circ} \mathrm{C}\right.$ to more than $\left.40^{\circ} \mathrm{C}\right)$ and even though most of the Vibrio sp. will grow in the $\mathrm{pH}$ between 6.5 and 9.0, it also tends to propagate best under alkaline surroundings [20]. As referred to both Pond A and Pond B in this study, the average temperature by triplicates measurement were recorded in between 29 to $30^{\circ} \mathrm{C}$ and the $\mathrm{pH}$ ranged between 7.42 to 7.93. $\mathrm{pH}$ of the water is one of the most important factors. $\mathrm{pH}$ of the pond water preferably ranging from 7.5 to 8.5.

Other parameter such as dissolved oxygen (DO), is the single parameter that affects the growth and production through its direct effect on the feeding and metabolism of shrimps and other environmental conditions. Toxic metabolites produced by bacterial activity causes DO depletion that weakens the shrimps and may cause mortality. The paddle wheel aerators must be operating when DO falls below the ideal level which is $5 \mathrm{ppm}$.

However, the preventive measure has been taken by the shrimp's farm prior stocking of the shrimp. The first layer surface of the land has been in contacted to the broth cultures of the shrimp were removed to detach the Vibrio spp. or other bacterial colonies that probably inhabited inside the sediment. Then, the limestone powder was spread to the whole area to neutralize the sediment. The main purposes of this process were to upsurge the availability of the nutrients, to sterilize the pond prior to the stocking process and to increase the $\mathrm{pH}$ and acting as buffer against the daily fluctuations of the $\mathrm{pH}$ [21]. The application of the limestone can help in rising the alkalinity for about $50 \mathrm{mg} / \mathrm{l}$ to develop the production through ponds fertilization and to improve the water quality of the ponds for the feed-based aquaculture [22].

Hydrated lime and burnt lime can initiate the rise of $\mathrm{pH}$, however it can be used to neutralize the acidic bottom of the pond by applying it to the bottom of the empty ponds. Hydrated or burnt lime also can help to disinfect the bottom of the pond and increase the $\mathrm{pH}$ even in low alkalinity or when acidic soil is absence. The sterilization process was done to clear the existence of the bacterial colonies and to prevent the infection of unwanted diseases to the cultures.

The harvesting process of the shrimp cultures were operated partially until the level of water inside the aquaculture farm were reduced and all the cultures were harvested. Hence, the amount of the Vibrio sp. was reduced as the results from the reduction of shrimp cultures. The technique involved the water exchange rates using clean water which can lessen Vibrio loads and decrease the impacts of stressors by washing out organic material and other metabolites such as ammonia [23].

Overused of antibiotics may develop resistance among shrimp pathogens and adjacent ecosystems. Increase in use of antibiotics would increase the difficulty of treating bacterial infections in the shrimp ponds. Several antibiotics such as fluoroquinolone, tetracycline, and sulphonamide need to take in for consideration in order to prevent high risk towards the environment and human health [24].

The high-risk sources include human and farm animals (e.g., poultry, swine, and dairy cattle) that are frequently exposed to antibiotics. The factor, such as the wide use of antibiotics in human therapy, resulted in the emergence of MAR pathogenic microorganisms in human feces, and subsequently, contamination of aquatic systems and environments. The resistance level may arise from a variety of selective pressure for the uncontrolled use of antibiotics, and besides, animal farms release their effluent and water following antibiotic 
therapy on the farms [25]. The results of antibiotics susceptibility test from this study provide valuable information in finding safe and efficient antibiotics application.

\section{CONCLUSION}

In conclusion, this study reported the importance of environmental parameters namely salinity, $\mathrm{pH}$ and temperature in influencing the distribution and abundance of Vibrio sp. in commercial shrimp farm. This study indicates the distribution of Vibrio sp. from sediment and water samples was decrease from the first phase of stocking compared to final phase of harvesting process. Continuous monitoring of the antimicrobial susceptibility profiles of Vibrio species is important to assure the safety of seafood production. The data obtained from this study may also be useful as a comparison with various data obtained from aquaculture shrimp farm from different countries and sources. It may provide new information in regards to the presence of Vibrio species in aquaculture shrimps ponds in Sarawak. Hence, further research should be conducted to monitor the prevalence of Vibrio sp. for one cycle of shrimp production to ensure product quality, safety and production consistency so that it will remain competitive in the global market.

\section{ACKNOWLEDGMENT}

Research fund was sponsored by FRGS/1/2019/STG05/UNIMAS/03/2 Universiti Malaysia Sarawak (Unimas) Kota Samarahan, Sarawak.

\section{REFERENCES}

[1] Food and Agriculture Organization of the United Nations (FAO), (2013) State of World Aquaculture: 2006. FAO, Rome.

[2] Food and Agriculture Organization of the United Nations (FAO), (2010) State of World Aquaculture: 2006. FAO, Rome.

[3] M. M. Ismail and A.M. Abdullah, "Shrimp trade competitiveness of Malaysia and selected ASEAN countries". J. Int. Food Agribus. Mark., vol 25, pp. 98 115, Oct. 2013.

[4] FAO Fisheries \& Aquaculture, (2002) Inland capture fishery statistics of Southeast Asia: current status and information needs, by D. Coates. Bangkok, FAO Regional Office for Asia and the Pacific, pp. 121.

[5] S. Chatterjee and S. Haldar, "Vibrio related disease in aquaculture and development of rapid and accurate identification methods". J. Mar. Sci., Res. Dev., Apr., 2012.

[6] J. Vandenberghe, F. L. Thompson, B. Gomez-Gill, and J. Swings, "Phenotypic diversity amongst Vibrio isolates from marine aquaculture systems". Aquaculture, vol. 219, no. $1-4$, pp. 9 - 20, Apr. 2003.

[7] N. Bhashkar, T. M. R. Setty, S. M. A. Mondal, C. V. Raju, B. S. Raghunath, and C. S. Anantha, "Prevalence of bacteria of public health significance in the cultured shrimp (Penaeus monodon)". Food Microbiol., vol. 15, pp. $511-519$, Oct. 1998.

[8] M. Vincent, C. S. W. Chan, and K. Apun, "Molecular confirmation and characterization of Vibrio parahaeolyticus from retailed fish". Inter. Food Res. J., vol. 22, pp. 1705 - 1710, Jan. 2015.

[9] S. Velmurugan, T. J. Shani, N. D. Senthil, A. T. Atnaf, S. Kumaran, and R. S. Pugazhvendan, "Isolation of Actinomycetes from shrimp culture pond and antagonistic to pathogenic Vibrio spp. and WSSV'. Int. J. Curr. Microbiol. Appl. Sci., vol. 4, no. 7, pp. 82-92, 2015.

[10]E. L. Elliot, C. A. Kaysner, L. Jackson, and M. L. Tamplin. (1995) Vibrio cholera, V. parahaemolyticus, V. vulnificus and other Vibrio spp. FDA Bacteriological Analytical Manual ( $8^{\text {th }}$ ed.).

[11]L. Noriega-Orozco, E. Acedo-Félix, I. Higuera-Ciapara, R. Jiménez-Flores, and R. Cano, "Pathogenic and nonpathogenic Vibrio species in aquaculture shrimp ponds". Rev. Latinoam. Microbiol., vol. 49, pp. 60 - 67, 2007.

[12] P. Baumann and R. H. W. Schubert. (1984) Family II. Vibrionaceae, pp. 516 - 550. Bergey's manual of systematic bacteriology. Volume 1.

[13] A. W. Bauer, M. M. Kirby, J. D. Sherrin, and M. Turch, "Antibiotics susceptibility testing by standardized single disk method". Am. J. Clin. Pathol., vol. 45, pp. 493 - 496, Apr. 1966.

[14] A. Noorlis, F. M. Ghazali, Y. K. Cheah. T. C. Tuan Zainazor, W. C. Wong, R. Tunung, C, F, Pui, M. Nishibuchi, Y. Nakaguchi, and R. Son, "Antibiotic resistance and biosafety of Vibrio cholera and Vibrio parahaemolyticus from freshwater fish at retail level". Int. Food Res. J., vol. 18, no. 4, pp. 1523 - 1530, 2011.

[15] S. Peddie and R. Wardle, "Crustaceans: The impact and control of vibriosis in shrimp culture worldwide". Aquac. Health Int., vol. August 4- 5, 2005.

[16] D. W. Meals. (2004). The Farmer's Guide to Agriculture and Water Quality Issues: Pathogens and Water Quality, 2004, USDA- CSREES, the U. S. EPA's National Agriculture Compliance Assistance Center and North Carolina State University Cooperative Extension. Raleigh, NC: US EPA and NC State University.

[17] Food and Agriculture Organization of the United States (FAO), (2019). Cultured aquatic species information programme. [Online]. Available: http://www.fao.org/fishery/culturedspecies/Penaeus_vann amei/en

[18] T. W. Flegel, "A future vision for disease control in shrimp aquaculture". J. World Aquac. Soc., vol 50, no. 2, pp. 249 - 266, Feb. 2019.

[19]L. Verschuere, G. Rombaut, P. Sorgeloos, and W. Verstraete, "Probiotic bacteria as biological control agents in aquaculture". Microbiol. Mol. Biol. Rev., vol. 64, no. 4, pp. 655 - 671, Dec. 2000.

[20] S. L. Percival and D. W. Williams. (2014). Vibrio. Microbiology of Waterborne Diseases, vol. 12, pp. 237 246. 
[21] M. L. Andy, E. C. Charles, and W. Craig. (1997). The use of lime in fish ponds. Department of School of Forest Resources and Conservation, Fisheries and Aquatic Sciences Program, UF/IFAS Extension. [Online]. Available: https://edis.ifas.ufl.edu/pdffiles/fa/fa02800.pdf

[22] B. Claude. (2017). Use of agricultural limestone and lime in aquaculture. Perspectives in Agricultural, Veterinary Science, Nutrition and Natural Resources.

[23] R. Barraza-Guardado, J. Arreola-Lizárraga, M., LópezTorres, R. Casillas-Hernández, A. Miranda-Baeza, F. Magallón-Barrajas, and C. Ibarra-Gámez, "Effluents of shrimp farms and its influence on the coastal ecosystems of Bahía de Kino, Mexico. Sci. World J., vol. 2013, pp. 1 -8 , Jun 2013.

[24] K. Holmström, S. Graslund, A. Wahlstrom, S. Poungshompoo, B. E. Bengtsson, and N. Katusky, "Antibiotic use in shrimp farming and implication for environmental impacts and human health". J. Food Sci. Technol., vol 38, no. 3, pp. 255 - 266, Mar. 2003.

[25]T. S. Schwach and E. A Zottola, "Use of scanning electron microscopy to demonstrate microbial attachment to beef and beef contact surfaces". J. Food Sci., vol. 47, no. 5 , pp. $1401-1405$, Sep. 1982.

\section{Contribution of Individual Authors to the Creation of a Scientific Article (Ghostwriting Policy)}

Elexson carried out the fully supervision and write up of the manuscripts

Nur Diyana Zakaria has organized and executed the quantification and isolation fo Vibrios

Dalene Lesen has carried out samples collection and proofreading of the manuscripts

Nur Hafizah Mohd Yusoff, has organized and executed the water samples analysis experiment.

Nurain Syahirah Binti Ismail has organized and executed the sediments analysis experiment

Teng Sing Tung has executed the analysis of the water and sediment samples.

Lesley Bilung has verified and analysis the whole experiment.

\section{Sources of Funding for Research Presented in a Scientific Article or Scientific Article Itself \\ Research fund was sponsored by FRGS/1/2019/STG05/UNIMAS/03/2, Universiti Malaysia Sarawak (Unimas) Kota Samarahan, Sarawak.}

Creative Commons Attribution License 4.0 (Attribution 4.0 International, CC BY 4.0)

This article is published under the terms of the Creative Commons Attribution License 4.0

https://creativecommons.org/licenses/by/4.0/deed.en_US 